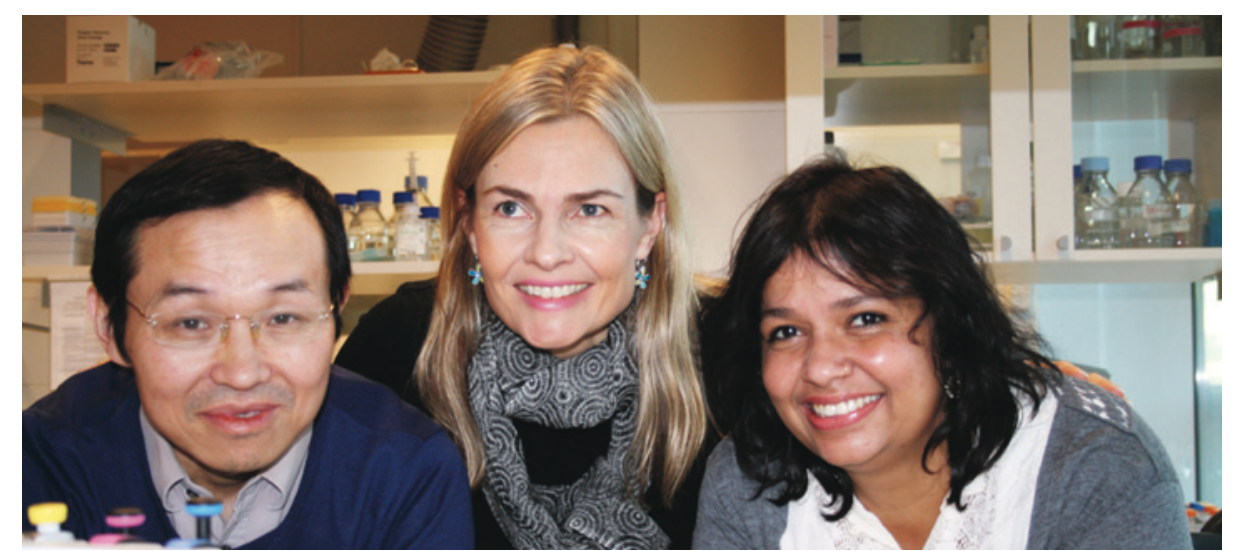

Medforfattere Weiwen Yang og Johanna Olweus og førsteforfatter Shraddha Kumari. Foto: privat

\section{T-celler mot kreft}

T-cellebasert immunterapi av kreft er effektivt, men begrenses av at det er vanskelig å finne angrepspunkter som T-cellene kan rettes mot. Resultater fra en norsk studie kan gjøre T-cellebasert immunterapi tilgjengelig for flere kreftformer gjennom ny teknologi som gjør at slike angrepspunkter kan finnes raskt.

Immunterapi, slik som terapeutiske antistoffer og genmodifiserte T-celler, er sentralt i utviklingen av en rekke nye behandlingsformer med betydelig forlenget levetid eller full kurasjon for kreftpasienter (1). Genmodifiserte T-celler har vært mye omtalt på mange vitenskapelige kongresser $\mathrm{og}$ i medier. Det er bl.a. vist at pasienter med hittil uhelbredelig B-celleleukemi er blitt kurert ved infusjon av pasientens egne Tceller, etter at cellene utenfor pasienten ble tilført kimeriske antigenreseptorer som gjør at de kan gjenkjenne det B-celle-spesifikke proteinet CD19 (2). Både friske og syke B-celler ble drept, men det er vist at man kan klare seg godt uten B-celler over tid.

En viktig begrensning for at denne typen T-celle-basert behandling skal kunne etableres for andre kreftformer, er at det har vært vanskelig å finne gode og spesifikke angrepspunkter i kreftcellene. Genmodifisering med kimeriske antigenreseptorer gjør det bare mulig å gjenkjenne angrepspunkter i cellemembranen. Gener som koder for T-cellereseptorer gjør det mulig for T-cellen å gjenkjenne angrepspunkter også inne i kreftcellen, der de fleste proteinene befinner seg.

- Vi har utviklet en ny teknologiplattform som gjør at man raskt kan finne gode angrepspunkter for T-cellereseptorer i kreftcellene og de cellene kreftsvulsten utgår fra, men ikke andre normale celler, sier professor og sisteforfatter Johanna Olweus.

- Denne teknologien tillater at man samtidig identifiserer effektive T-cellereseptorer mot disse angrepspunktene, som kan danne utgangspunkt for ny immunterapi.
T-cellereseptorer kan sammenliknes med målstyrte raketter, som detoneres først etter at T-cellen har funnet sitt mål. Behandlingen egner seg for kreft $i$ organer vi kan unnvære eller som kan erstattes ved transplantasjon, sier Olweus.

\section{K.G. Jebsen-senter for immunterapi mot kreft}

Johanna Olweus er leder for det nyoppstartede K.G. Jebsen-senter for immunterapi mot kreft ved Universitetet i Oslo, som har hovedsete ved Oslo universitetssykehus, Radiumhospitalet. Forskningen har vært et samarbeidsprosjekt mellom hennes gruppe og Fridtjof Lund-Johansens gruppe ved Rikshospitalet og Ton N. Schumachers gruppe ved The Netherlands Cancer Institute, alle partnere i senteret. Shraddha Kumari, studiens førsteforfatter, er postdoktorforsker i Olweus' gruppe. Samarbeidet på tvers av gruppene har vært sentralt for utviklingen av teknologien. Den viktigste målsettingen er å generere innovative strategier for å bryte pasientens toleranse for egen kreft.

\section{Matilde Risopatron Berg}

Tidsskriftet

\section{Litteratur}

1. Kumari S, Wälchli S, Fallang LE et al. Alloreactive cytotoxic T cells provide means to decipher the immunopeptidome and reveal a plethora of tumorassociated self-epitopes. Proc Natl Acad Sci U S A 2014; 111: 403-8.

2. Kalos M, Levine BL, Porter DL et al. T cells with chimeric antigen receptors have potent antitumor effects and can establish memory in patients with advanced leukemia. Sci Transl Med 2011; 3 : $95 \mathrm{ra} 73$.
Ordforklaringer:

T-celler: Hvite blodceller som beskytter oss mot infeksjoner, og som bl.a. er essensielle for å kurere oss for virussykdommer. T-cellene «skanner» alle kroppens celler for tilstedeværelse av proteinfragmenter (peptider) fra fremmede og skadelige agens (f.eks. virus) som har infisert cellene. De har en unik evne til spesifikt å gjenkjenne slike peptider gjennom sin T-cellereseptor

T-cellereseptor: En T-cellereseptor gjenkjenner et bestemt vevstypemolekyl som viser frem et peptid (proteinfragment) som stammer fra et nedbrutt protein i målcellen. På den

måten kan T-cellene gjenkjenne et hvilket som helst protein, intra- eller ekstracellulært, fra målcellen. T-cellene har et stort repertoar av T-cellereseptorer som kan binde seg til ulike peptider i kompleks med vevstypemolekyler på overflaten av nesten alle kroppens celler. Når en T-cellereseptor binder et slikt målkompleks på en celle, kan T-cellen aktiveres til å drepe målcellen.

Genmodifisering: Ulike teknologiske løsninger kan velges for å tilføre gener som permanent utstyrer de genmodifiserte T-cellene med nye egenskaper, der den vanligste løsningen i dag er overføring ved hjelp av retro-/lentivirus som infiserer cellen. T-cellene som modifiseres med gener som koder for en T-cellereseptor, kan da få evnen til spesifikt å gjenkjenne et bestemt angrepspunkt som finnes i kreftcellen.

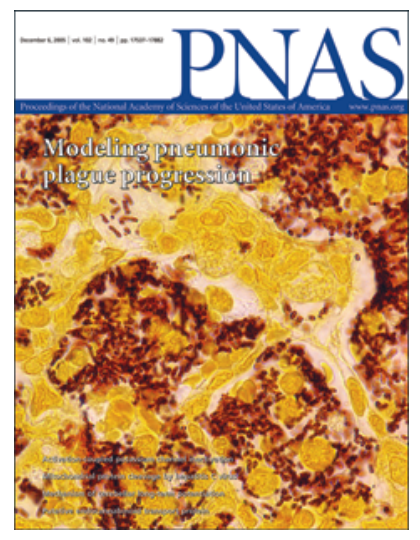

>Artikkelen ble e-publisert 16.12. 2013 i det anerkjente tidsskriftet Proceedings of the National Academy of Sciences 